\title{
Fase Menstrual na data da Cirurgia para Câncer de Mama. Resultados Tardios e Taxas de Sobrevida Assintomática
}

\author{
Timing of Surgery during Menstrual Cycle, Late Results and Disease-Free Survival \\ Rates in 130 Patients with Breast Carcinoma
}

Antonio Franco Montoro, Flávio Franco Montoro, José Solis Rivera.

\section{Referências}

1. Badwe RA, Gregory WM, Chaudary MA, Richards MA, Bentley AE, Rubens RD, et al. Timing of surgery during menstrual cycle and survival of premenopausal women with operable breast cancer. Lancet 1991;337:1261-4.

2. D’Eredita G, De Leo G, Punzo C, Neri V, Losacco T, Pitzalis $\mathrm{V}$, et al. Timing of breast cancer surgery during menstrual cycle. A ten-year analysis of 133 premenopausal women. Breast 1995;4:258.

3. Hrushesky WJM, Bluming AZ, Gruber SA. Menstrual influence on surgical cure of breast cancer. Lancet 1989; 335:984.

4. Gelber RD, Goldhirsch, A. Menstrual effect on surgical cure of breast cancer. Lancet 1989; $2: 1343-4$.

5. Nicholson S, Sainsbury JR, Halcrow P, Chambers P, Farndon JR, Harris AL. Expression of epidermal growth factor receptors associated with lack of response to endocrine therapy in recurrent breast cancer. Lancet 1989; 1:182-5.

6. Oliver DJ, Ingram DM. Timing of surgery during the menstrual cycle for breast cancer: possible role of growth factors. Eur J Cancer 1995; 31A:325-28.

7. Ratajczak HV, Sothern RB, Hrushesky WJ. Estrous influence on surgical cure of a mouse breast cancer. J Exp Med 1988;168:73-83.
8. Saad Z, Bramwell V, Duff J, Girotti M, Jory T, Heathcote G, et al. Timing of surgery in relation to the menstrual cycle in premenopausal women with operable breast cancer. Br J Surg 1994;81:217-20.

9. Sainsbury JR, Fandon JR, Needham GK, Malcolm AJ, Harris AR. Epidermal growth factor receptor status as a predictor of early recurrence of and death from breast cancer. Lancet $1987 ; 1: 1398$ 402.

10.Senie RT, Rosen PP, Rhodes P, Lesser ML. Timing of breast cancer excision during the menstrual cycle influences duration of disease-free survival. Ann Intern Med 1991;115:337-42.

11.Stonelake PS, Powel J, Dunn JA, Warwick J, Bramhall SR, Neoptolemos JP et al. Influence of timing of surgery during menstrual cycle on survival of premenopausal women with operable cancer. Breast 1995;4:19-24

12.Powles TJ, Ashley SE, Nash AG, Tidy A. Timing of surgery in breast cancer. Lancet 1991; 337:1603-5

13.Veronesi U, Luini, A, Mariani L, Del Vecchio M, Alvez $\mathrm{D}$, Andreoli C, et al. Effect of menstrual phase on surgical treatment of breast cancer. Lancet 1994; 343: 1545-7.

14.Von Minckwitz G, Kaufmann M, Dobberstein S, Grischke M, Diel EJ. Surgical procedure can explain varying influence of menstrual cycle on prognosis of premenopausal breast cancer patients. Breast 1995;4:29-32. 